\title{
Biflavones from Platonia insignis Mart. Flowers Promote In Vitro Antileishmanial and Immunomodulatory Effects against Internalized Amastigote Forms of Leishmania amazonensis
}

\author{
Érika Alves Bezerra ${ }^{1}$, Michel Mualém de Moraes Alves ${ }^{2}$, Simone Kelly Rodrigues Lima ${ }^{1,3}$, \\ Emanuelly Elanny Andrade Pinheiro ${ }^{4}$, Layane Valéria Amorim ${ }^{2}$, José de Sousa Lima Neto ${ }^{5}$, \\ Fernando Aécio de Amorim Carvalho ${ }^{2}$, Antônia Maria das Graças Lopes Citó ${ }^{4}$ \\ and Daniel Dias Rufino Arcanjo $1, *$ (1)
}

check for

updates

Citation: Bezerra, É.A.; Alves, M.M.d.M.; Lima, S.K.R.; Pinheiro, E.E.A.; Amorim, L.V.; Lima Neto, J.d.S.; Carvalho, F.A.d.A.; Citó, A.M.d.G.L.; Arcanjo, D.D.R. Biflavones from Platonia insignis Mart. Flowers Promote In Vitro Antileishmanial and Immunomodulatory Effects against Internalized Amastigote Forms of Leishmania amazonensis. Pathogens 2021, 10, 1166. https://doi.org/ 10.3390 / pathogens10091166

Academic Editors: Abhay Satoskar, Hira L Nakhasi and Shinjiro Hamano

Received: 19 July 2021

Accepted: 30 August 2021

Published: 10 September 2021

Publisher's Note: MDPI stays neutral with regard to jurisdictional claims in published maps and institutional affiliations.

Copyright: (c) 2021 by the authors. Licensee MDPI, Basel, Switzerland. This article is an open access article distributed under the terms and conditions of the Creative Commons Attribution (CC BY) license (https:/ / creativecommons.org/licenses/by/ $4.0 /)$.
1 Department of Biophysics and Physiology, Federal University of Piauí, Teresina 64049-550, Brazil; erikka.ab@gmail.com (É.A.B.); simonelima.nut@gmail.com (S.K.R.L.)

2 Medicinal Plants Research Center, Federal University of Piauí, Teresina 64049-550, Brazil; mualemmichel@ufpi.edu.br (M.M.d.M.A.); layane.valeria@hotmail.com (L.V.A.); famorim@ufpi.edu.br (F.A.d.A.C.)

3 Department of Education, Federal Institute of Maranhão, Bacabal 65080-805, Brazil

4 Department of Chemistry, Federal University of Piauí, Teresina 64049-550, Brazil; emanuellyeandradep@gmail.com (E.E.A.P.); gracito@ufpi.edu.br (A.M.d.G.L.C.)

5 Faculty of Pharmacy, Federal University of Piauí, Teresina 64049-550, Brazil; limaneto@ufpi.edu.br

* Correspondence: daniel.arcanjo@ufpi.edu.br; Tel.: +55-86-98845-9526

\begin{abstract}
Leishmaniasis is an infectious disease that affects millions of people worldwide, making the search essential for more accessible treatments. The species Platonia insignis Mart. (Clusiaceae) has been extensively studied and has gained prominence for its pharmacological potential. The objective of this work was to evaluate the antileishmania activity, cytotoxic effect and activation patterns of macrophages of hydroalcoholic extract (EHPi), ethyl acetate fractions (FAcOEt) and morelloflavone/volkensiflavone mixture (MB) from P. insignis flowers. EHPi, FAcOEt and MB demonstrated concentration-dependent antileishmania activity, with inhibition of parasite growth in all analyzed concentrations. EHPi exhibited maximum effect at $800 \mu \mathrm{g} / \mathrm{mL}$, while FAcOEt and $\mathrm{MB}$ reduced the growth of the parasite by $94.62 \%$ at $800 \mu \mathrm{g} / \mathrm{mL}$. EHPi, FAcOEt and MB showed low cytotoxic effects for macrophages at $81.78,159.67$ and $134.28 \mu \mathrm{g} / \mathrm{mL}$, respectively. EHPi $(11.25 \mu \mathrm{g} / \mathrm{mL})$, FAcOEt $(11.25$ and $22.5 \mu \mathrm{g} / \mathrm{mL})$ and MB $(22.5 \mu \mathrm{g} / \mathrm{mL})$ characterized the increase in lysosomal activity, suggesting a possible modulating effect. These findings open for the application of flowers from a P. insignis flowers and biflavones mixture thereof in the promising treatment of leishmaniasis.
\end{abstract}

Keywords: antileishmanial activity; cytotoxicity in macrophages; medicinal plants; immunomodulation; natural products; hydroalcoholic extract; ethyl acetate fraction; biflavone mixture; Platonia insignis

\section{Introduction}

Neglected tropical diseases (NTDs), prevalent in tropical and subtropical regions, affect more than one billion people worldwide and mainly affect populations living in poorer regions where hygiene, food and sanitation conditions are more precarious and where they are exposed to infectious vectors and domestic animals [1]. Leishmaniasis continues to be a major health problem of the world. There are four main forms of the disease: visceral leishmaniasis, post-kala-azar dermal leishmaniasis, cutaneous leishmaniasis and mucocutaneous leishmaniasis. Visceral leishmamiasis is the most serious and is almost always fatal untreated, while cutaneous is the most common [2].

Leishmaniasis is a complex of infectious parasitic diseases caused by protozoa of the genus Leishmania, which are transmitted by the bite of infected female phlebotomine 
sandflies [1]. Among them, leishmaniasis is estimated to be second in mortality and fourth in morbidity. An estimated 700,000 to 1 million new cases occur annually. [1,3]. The drug of first choice for the treatment of leishmaniasis is $\mathrm{N}$-methyl glucamine antimoniate, known commercially as Glucantime ${ }^{\circledR}$, and Amphotericin B is the second choice [4,5]. However, the currently available treatment requires continuous clinical and laboratory monitoring, exhibits severe side effects, leads to intolerance, sometimes causes treatment dropout, and is expensive [6]. In this context, it is essential to search for new treatments that have low toxicity and lower cost and are easily accessible.

Medicinal plants have become an alternative in the search for substances with antileishmanial activity because they are promising sources for the synthesis of a wide variety of new drugs due to the magnitude of their biodiversity and the amount of biologically active chemical compounds they contain $[7,8]$.

Platonia insignis Mart. (Clusiaceae family) is a promising species in the search for bioactive compounds. It is widely used in the treatment of skin diseases, spider and snake bites, rheumatic arthritis and is also used as a cicatrizing agent [9]. Trials performed with the seeds of the fruits have demonstrated wound-healing and anti-inflammatory activities [10], anticonvulsant [11], antileishmania [12], immunomodulatory [13], antimicrobial and antiinflammatory activities [10]. Furthermore, the fruit pulp has an antioxidant activity [14], and the fruit peels have been used for the treatment of eczema and arthritis [15].

In our group, Silva et al. [16] isolated and identified a mixture of two biflavonoids (moreloflavone and volkensiflavone) and a polyisoprenylated benzophenone garcinielliptona FC (GFC) from the hydroalcoholic extract of $P$. insignis flowers. These compounds have proven to be responsible for important pharmacological activities attributed to the species. Anti-HIV activity [17], antibacterial [18], anti-inflammatory [19], antioxidant [20] and antiparasitic activities [21] were associated with morelloflavone, while volkensiflavone was reported to have analgesic, antibacterial and antitumor activities [20].

In view of the above, the components of $P$. insignis deserve to be highlighted as a potential novel source of compounds for the chemotherapy of leishmaniasis, and for which treatment is a critical problem.

\section{Results}

\subsection{Effect of EHPi, FAcOet and $M B$ on Promastigotes of L. amazonensis}

EHPi, FAcOEt and MB demonstrated concentration-dependent antileishmanial activity with inhibition of parasite growth at all concentrations analyzed. EHPi exhibited maximum effect at $800 \mu \mathrm{g} / \mathrm{mL}$, while FAcOEt and MB reduced parasite growth by $94.62 \%$ at $800 \mu \mathrm{g} / \mathrm{mL}$. The $50 \%$ inhibitory concentration $\left(\mathrm{IC}_{50}\right)$ values obtained from the assay on promastigotes are shown in Table 1.

Table 1. Antileishmania activity and cytotoxic effects against mammalian cells for EHPi, FAcOEt and $\mathrm{MB}$ and amphotericin B (Amph B).

\begin{tabular}{cccccc}
\hline Compounds & $\begin{array}{c}\text { Macrophages } \\
\text { CC50 } \\
(\boldsymbol{\mu g} / \mathbf{m L})\end{array}$ & $\begin{array}{c}\text { Red Cells } \\
\text { CH50 } \\
(\boldsymbol{\mu} \mathbf{g} / \mathbf{m L})\end{array}$ & $\begin{array}{c}\text { Promastigotes } \\
\text { EC50 } \\
(\boldsymbol{\mu g} / \mathbf{m L})\end{array}$ & $\begin{array}{c}\text { Intramacrophage } \\
\text { Amastigotes } \\
\text { EC50 }(\boldsymbol{\mu g} / \mathbf{m L}) \mathbf{S I}_{\mathbf{m}}\end{array}$ \\
\hline EHPi & 81.78 & $\mathrm{NT}$ & 30.05 & 6.08 & 38.55 \\
FacOEt & 159.67 & $\mathrm{NT}$ & 23.05 & 13.44 & 3.55 \\
$\mathrm{MB}$ & 134,28 & $\mathrm{NT}$ & 45.71 & 16.33 & 0.20 \\
Amph B & 8.75 & $\mathrm{NT}$ & 1.74 & 9.81 & 43.75 \\
\hline
\end{tabular}

SI, selectivity index; $\mathrm{SI}_{\mathrm{m}}$, selectivity index intramacrophage amastigotes; NT, non-toxic at tested concentrations $\mathrm{EHPi}$, hydroalcoholic extract; FacOEt, ethyl acetate fractions; MB, morelloflavone/volkensiflavone mixture; Amph B, amphotericin B.

\subsection{Cytotoxicity and Hemolysis Assay}

EHPi, FAcOEt and MB showed low cytotoxic effects for murine macrophages and sheep erythrocytes (Figure 1). There was a statistically significant reduction in macrophage viability by MTT assay from the lowest concentration tested $(6.25 \mu \mathrm{g} / \mathrm{mL})$ for EHPi, while 
for FAcOEt and $\mathrm{MB}$, the reduction occurred from 50 and $25 \mu \mathrm{g} / \mathrm{mL}$, respectively, with CC50 of $81.78 \mu \mathrm{g} / \mathrm{mL}$ for EHPi, $159.67 \mu \mathrm{g} / \mathrm{mL}$ for FAcOEt and $134.28 \mu \mathrm{g} / \mathrm{mL}$ for MB. Amphotericin B, conversely, a drug that shows high toxicity against murine macrophages, showed CC50 of $8.75 \mu \mathrm{g} / \mathrm{mL}$ (Table 1). At the maximum concentration tested $(800 \mu \mathrm{g} / \mathrm{mL}$ ), EHPi reduced RBC viability by $4.81 \%$, while FAcOEt and MB reduced it by $11.74 \%$ and $12.86 \%$, respectively.
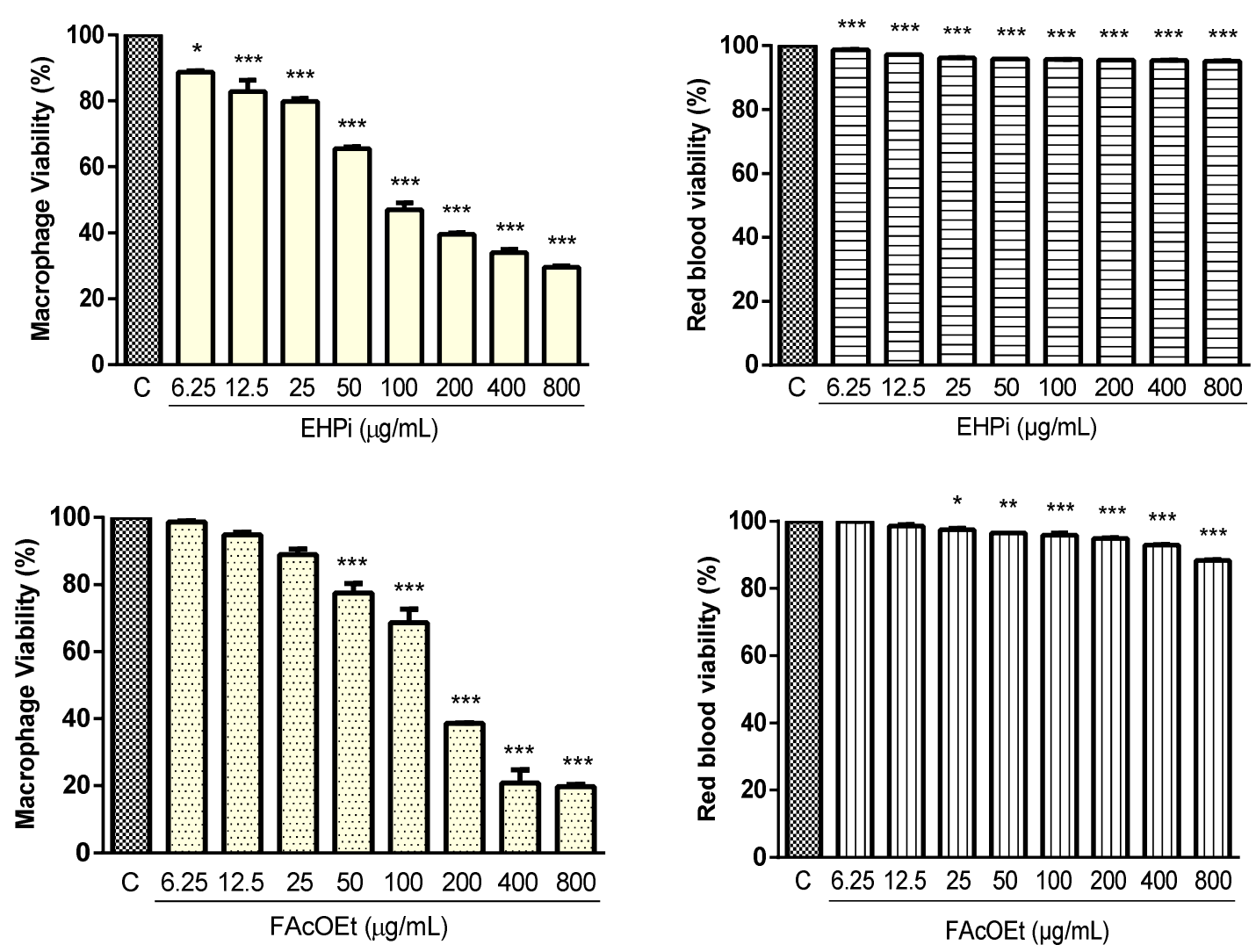

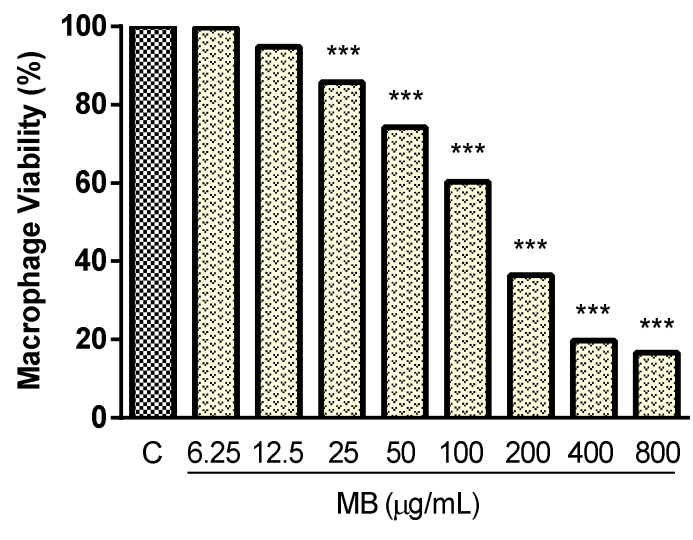

(a)

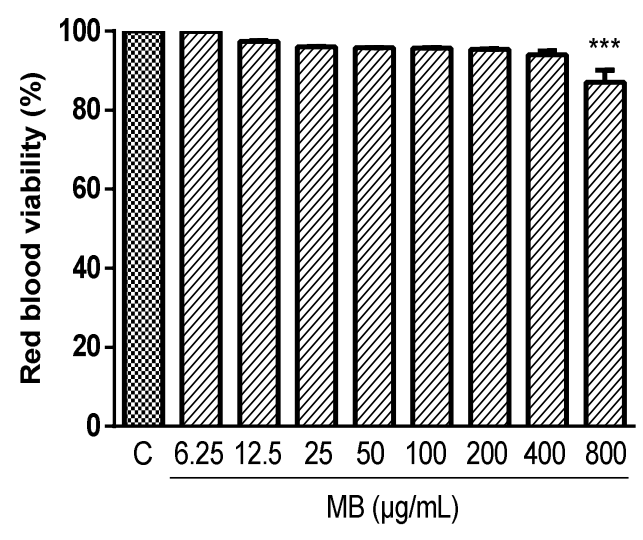

(b)

Figure 1. Cytotoxic effects of EHPi, FAcOEt and MB against BALB/c murine peritoneal macrophages (a) and sheep red blood cells (b). Macrophages and red blood cells were incubated with GFC for $48 \mathrm{~h}$. Macrophage viability was evaluated using tetrazolium salt (MTT) test. Data are presented as mean \pm SEM of three experiments performed in triplicate. ${ }^{*} p<0.05$; ${ }^{* *} p<0.01 ;{ }^{* *} p<0.001$ when compared with control (C) or Amph B. One-way ANOVA followed by Bonferroni's post hoc test. 


\subsection{Effects of EHPi, FAcOEt and MB on L. amazonensis Infection of Macrophages}

EHPi at concentrations of 7.5 and $15 \mu \mathrm{g} / \mathrm{mL}$ and $\mathrm{MB}$ at concentrations of 30 and $60 \mathrm{\mu g} / \mathrm{mL}$ reduced the number of infected macrophages compared to control, but when compared to amphotericin B, there were no significant reductions. FAcOEt at 15 and $30 \mu \mathrm{g} / \mathrm{mL}$ and $\mathrm{MB}$ at $15 \mu \mathrm{g} / \mathrm{mL}$ showed no action on reducing infection. However, EHPi at $30 \mu \mathrm{g} / \mathrm{mL}$ and FAcOEt at $60 \mu \mathrm{g} / \mathrm{mL}$ reduced infection by $68 \%$ and $62.66 \%$ respectively, while amphotericin B decreased the number of infected macrophages to approximately $86 \%$ of the concentration of $0.2 \mu \mathrm{g} / \mathrm{mL}$ (Figures 2 and 3 ).
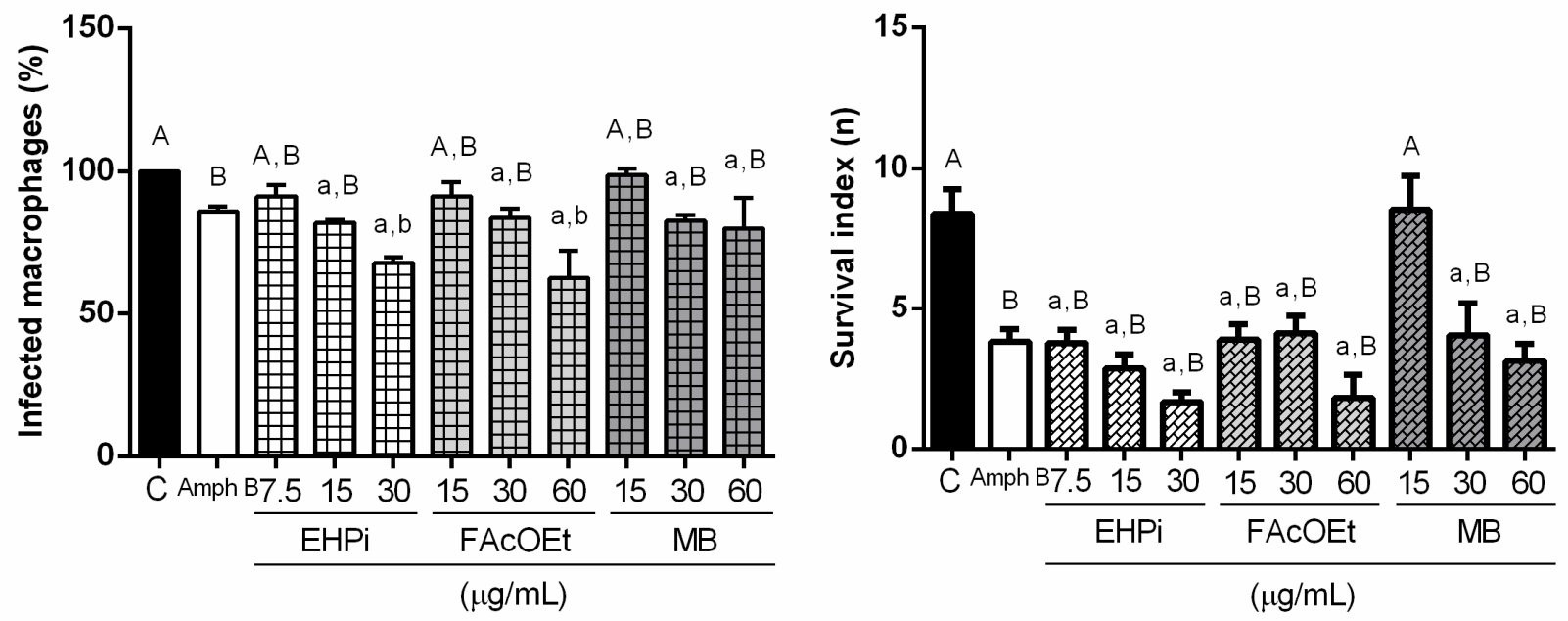

Figure 2. Effects of EHPi, FAcOEt and MB and amphotericin B on infected macrophages and survival index of BALB/c murine macrophages infected with L. amazonensis. Cells were treated with GFC or Amph B for 48 h. Data are presented as mean \pm SEM of three experiments performed in triplicate. " $\mathrm{A}$ " and " $\mathrm{B}$ " when it does not differ statistically from the control (C) or amphotericin B (Amph B), respectively; " $a$ " and " $b$ " when differences between control (C) or Amph B, respectively, are significant. One-way ANOVA followed by Bonferroni's post hoc test.

\subsection{Determination of Lysosomal Activity and Phagocytic Capacity}

To evaluate the activation mechanisms of macrophages induced by EHPi, FAcOEt and $\mathrm{MB}$, the capacity of these cells, when activated, to retain neutral red and zymosan particles, was analyzed by incubating the test samples (EHPi, FAcOEt and MB) with macrophages infected with L. amazonensis. EHPi promoted a statistically significant increase in lysosomal volume at the concentration of $11.25 \mu \mathrm{g} / \mathrm{mL}$, and at higher concentrations, there begins to be a concentration-dependent reduction in activation (Figure 4a). EHPi did not induce an increase in the phagocytic capacity of macrophages for any of the concentrations tested (5.625 to $90 \mu \mathrm{g} / \mathrm{mL}$ ) (Figure 4b). FAcOEt promoted increased lysosomal volume at concentrations of 11.25 and $22.5 \mu \mathrm{g} / \mathrm{mL}$, and although at concentrations of 45 and $90 \mu \mathrm{g} / \mathrm{mL}$ there was a reduction in activation, its volume remained larger than that of the control. $\mathrm{MB}$ induced increased lysosomal volume at the concentration of $22.5 \mu \mathrm{g} / \mathrm{mL}$. FAcOEt and MB induced a statistically significant increase in the phagocytic capacity of macrophages at all concentrations analyzed (5.625 to $90 \mu \mathrm{g} / \mathrm{mL}$ ). 


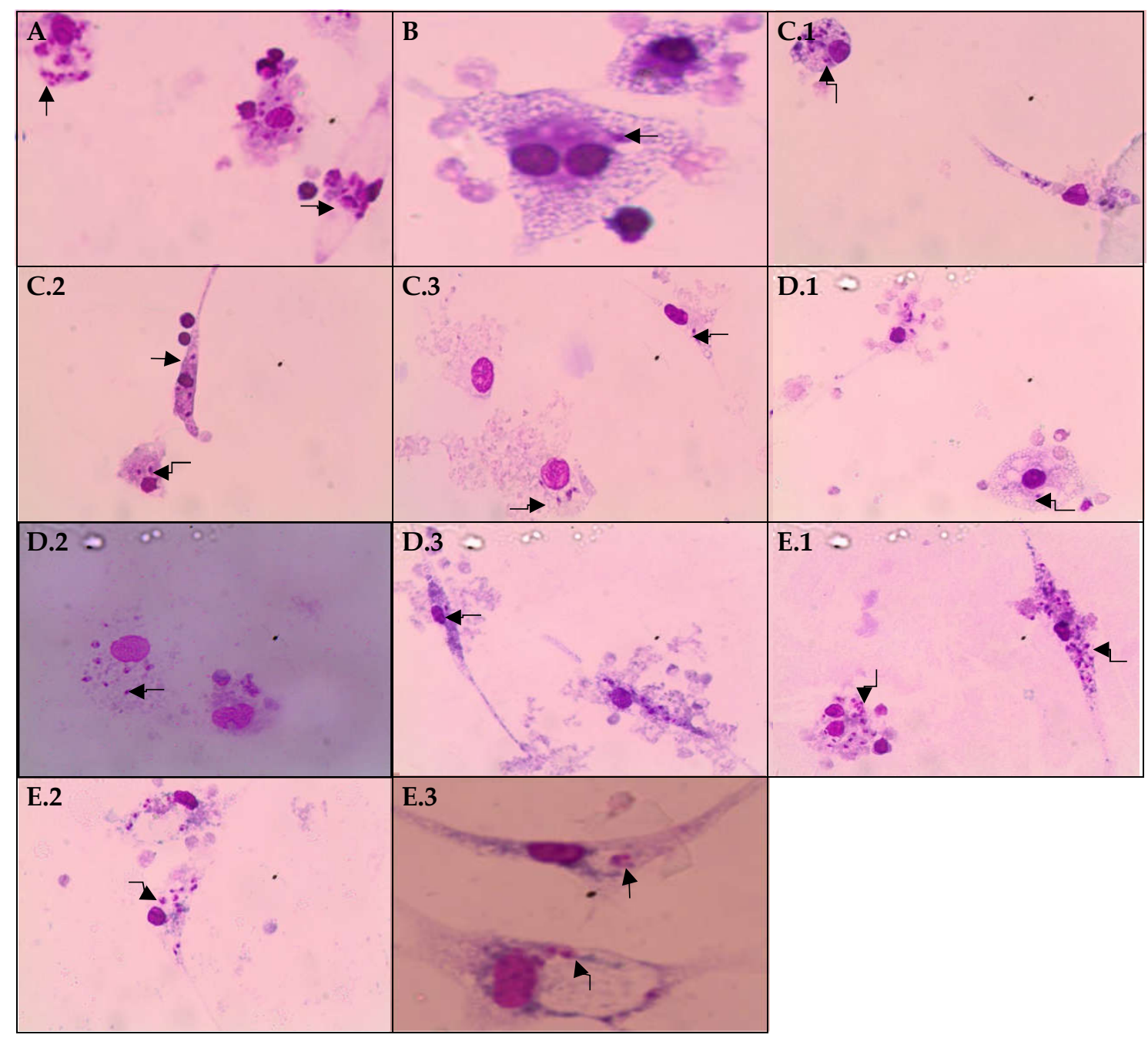

Figure 3. Macrophages experimentally infected by Leishmania amazonensis (A). Amph B was used as a positive control at the concentration of $0.2 \mu \mathrm{g} / \mathrm{mL}$ (B). For EHPi treatment, concentrations of 7.5 (C.1), 15 (C.2), and $30 \mu \mathrm{g} / \mathrm{mL}$ (C.3) were used, for FAcOEt treatment, concentrations of 15 (D.1), 30 (D.2) and $60 \mu \mathrm{g} / \mathrm{mL}$ (D.3) and for MB treatment, concentrations of 15 (E.1), 30 (E.2) and $60 \mu \mathrm{g} / \mathrm{mL}$ (E.3). The arrows indicate macrophage-internalized amastigote forms of L. amazonensis.

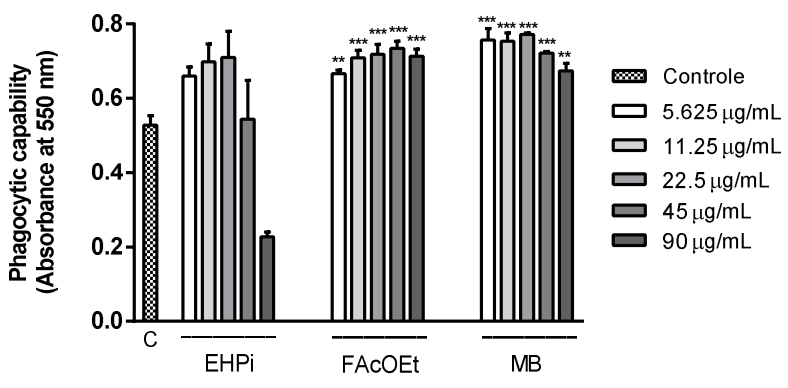

(a)

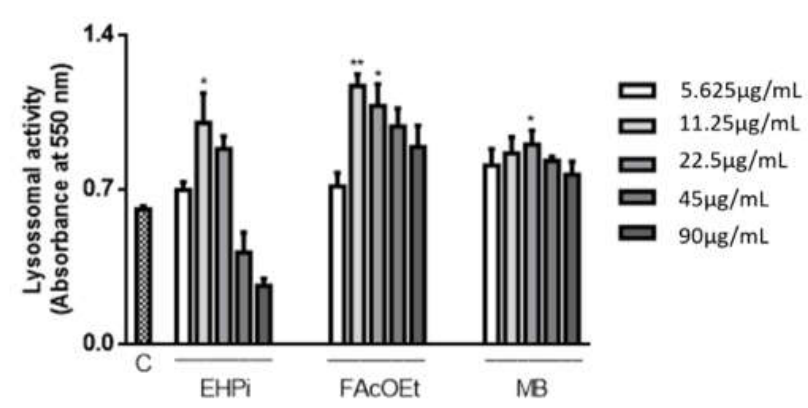

(b)

Figure 4. Effects of EHPi, FAcOEt and MB on lysosomal activity (a) and phagocytic capability (b). Murine peritoneal macrophages were treated at ranging concentrations for $48 \mathrm{~h}$. Lysosomal activity and phagocytic capacity were assessed by quantification of neutral red (NR). Phagocytic capability was assessed by the incorporation of zymosan to NR, solubilized by the extraction solution. Data are presented as mean \pm SEM of three experiments performed in triplicate. ${ }^{*} p<0.05$; ${ }^{* *} p<0.01 ;{ }^{* * *} p<0.001$ when compared with control (C). One-way ANOVA followed by Bonferroni's post hoc test. 


\subsection{Determination of Nitrite Production}

The evaluation of nitric oxide induction by macrophages is given by quantifying the concentration of nitrite present in the medium. EHPi did not induce NO production at any of the concentrations analyzed (5.625 to $90 \mu \mathrm{g} / \mathrm{mL}$ ), whereas FAcOEt and MB significantly increased NO production at the concentration of $11.25 \mu \mathrm{g} / \mathrm{mL}$ (Figure 5).

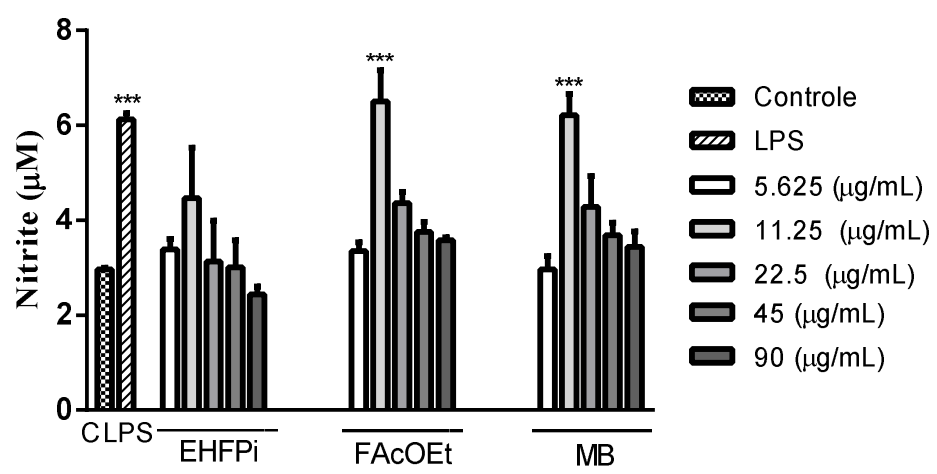

Figure 5. Nitrite measurement in infected or non-infected BALB/c murine peritoneal macrophages treated with EHPi, FAcOEt and MB for $24 \mathrm{~h}$. The culture supernatant was mixed in equal parts with the Griess reagent. LPS (lipopolysaccharide from Escherichia coli; $2 \mu \mathrm{g} / \mathrm{mL}$ ) was used as positive control. Data are presented as mean \pm SEM of three experiments performed in triplicate. ${ }^{* *} p<0.05$ when compared with control group ${ }^{* * *} p<0.05$ when compared with LPS group. One-way ANOVA followed by Bonferroni's post hoc test.

\section{Discussion}

Medicinal plants have shown to be a promising alternative for the treatment of various diseases, including leishmaniasis [22,23]. The drugs currently available for the treatment of this pathology are limited and present high risks of toxicity for patients [24]. Among the great diversity of the Brazilian flora, Platonia insignis, belonging to the Clusiaceae family, deserves to be highlighted.

Assays performed with the seeds of Platonia fruits demonstrated potential antileishmanial activity, with $\mathrm{IC}_{50}$ of $25.78 \mu \mathrm{g} / \mathrm{mL}$, for Garcinielliptone FC (GFC) on promastigote forms of L. amazonensis [12]. The ethanolic extract, fukugetin and morelloflavone obtained from the fruits of Garcinia brasiliensis, also belonging to the Clusiaceae family, showed antileishmanial action on L. amazonensis promastigotes forms, with $\mathrm{IC}_{50}$ of $15,3.2$, and $0.1390 \mu \mathrm{M}$, respectively. Morelloflavone showed $\mathrm{IC}_{50} 0.2900 \mu \mathrm{M}$ on amastigotes. The samples, EHPi, FAcOEt and MB promoted inhibition of the growth of L. amazonensis promastigotes at all concentrations analyzed, with $\mathrm{IC}_{50}$ of $30.80,23.04$ and $45.71 \mu \mathrm{g} / \mathrm{mL}$, but with antileishmanial action at concentrations considerably higher than that of amphotericin B.

The use of medicinal plants for the prevention, alleviation of symptoms and cure of diseases is a widespread practice worldwide [25]. However, they are widely used indiscriminately, which can cause cytotoxic and genotoxic alterations that lead to the development of other pathologies [26]. It is important that studies that analyze the action of natural products at the cellular level be conducted in order to ensure the safe use by the population as well as to support further studies [27]. Cytotoxicity, MTT and hemolytic activity assays, performed with EHPi, FAcOEt and MB showed low cytotoxicity for macrophages, essential cells in the defense mechanisms of leishmaniasis, and for sheep erythrocytes, with $\mathrm{CH} 50$ being at concentrations well above $800 \mu \mathrm{g} / \mathrm{mL}$, indicating greater selectivity for the parasite than for mammalian cells. Cytotoxicity assays with the hexanic extract of bacuri fruit seeds showed similar results, with a CH50 of $90.03 \mu \mathrm{g} / \mathrm{mL}$ for murine macrophages, with a confidence interval between 70.72 and $114.6 \mu \mathrm{g} / \mathrm{mL}$ and $3 \%$ hemolysis in human erythrocytes at the concentration of $400 \mu \mathrm{g} / \mathrm{mL}$ [13], reaffirming its use as safe. 
Immunostimulation is essential and effective in the prevention and treatment of diseases that compromise the immune system. Medicinal plants have become a promising alternative in the development of drugs for this purpose, proving to be adequate in the prevention and treatment of infections [28]. The existing dichotomy between Th1 and Th2 immune cell response in patients affected by leishmaniasis has led to the investigation of therapeutic alternatives that direct immunomodulatory effect to the Th1 response and not only target the parasite [29]. Macrophages play a central role in modulating the immune response, and several systems are activated in order to fight an infection. It is possible to evaluate the ability that many chemical compounds have to activate these cells through in vitro assays [30,31]. EHPi $(11.25 \mu \mathrm{g} / \mathrm{mL})$, FAcOEt $(11.25$ and $22.5 \mu \mathrm{g} / \mathrm{mL})$ and MB $(22.5 \mu \mathrm{g} / \mathrm{mL})$ retained neutral red particles, characterizing increased lysosomal activity. Increased lysosomal activities, thus, suggest a possible defense of these cells. These data are in agreement with the study conducted by Lustosa et al. [13], in which the hexanic extract (EHSB), produced from the seeds of the fruits, promoted an increase in lysosomal volume at concentrations of $12.5,25$ and $50 \mu \mathrm{g} / \mathrm{mL}$. The activation of macrophages by using zymosan particles stained with neutral red was another parameter evaluated. Zymosan stimulates defense cells to induce Th1-type response, leading to an increase in interferon gamma (IFN) production and phagocytic capacity [32]. Although the extract did not activate this mechanism, FAcOEt and MB (5.625 to $90 \mu \mathrm{g} / \mathrm{mL})$ induced statistically significant increases in the phagocytic capacity of macrophages. Lustosa et al. [13] demonstrated that EHSB induced increased phagocytic capacity of macrophages by $42.9 \%, 49.8 \%, 53.7 \%$ and $71.2 \%$ at concentrations of $25,12.5,6.25$ and $3.12 \mu \mathrm{g} / \mathrm{mL}$, respectively. The cytotoxic effect against pathogenic microorganisms is indirectly realized by nitric oxide (NO) produced by macrophages in the processes of inflammation, angiogenesis and defense mechanisms against pathogenic microorganisms [33,34]. Its synthesis is considered one of the most important defense mechanisms, as the parasite is able to inhibit the expression or activity of the inducible nitric oxide synthase (iNOS) enzyme to survive inside macrophages [35]. FAcOEt $(11.25 \mu \mathrm{g} / \mathrm{mL})$ and $\mathrm{MB}(11.25 \mu \mathrm{g} / \mathrm{mL})$ promoted increased NO production, and reduced activation of these mechanisms was observed at higher concentrations. Possibly, the higher concentrations tested lead to reduced cell viability. In the study conducted by Lustosa et al. [13], the hexanic extract induced NO production at all concentrations analyzed ( 3.12 to $100 \mu \mathrm{g} / \mathrm{mL}$ ). The mechanisms of antiparasitic action of flavonoids are not yet evidenced, but it is known that they exert an effect on the generation of reactive oxygen species [36] and increase the production of pro-inflammatory cytokines, such as IFN [37].

$\mathrm{BALB} / \mathrm{c}$ murine peritoneal macrophages were infected with promastigotes of L. amazonensis and incubated with $\mathrm{EHPi}, \mathrm{FAcOEt}$ and $\mathrm{MB}$ to evaluate infection and infectivity compared with control. EHPi $(30 \mu \mathrm{g} / \mathrm{mL})$ and FAcOEt $(60 \mu \mathrm{g} / \mathrm{mL})$ statistically reduced macrophage infection but were not able to reduce infectivity when compared to positive control (amphotericin B).

The findings suggest that EHPi, FAcOEt, and MB may possibly be used as a supportive therapy to conventional antileishmania chemotherapy, as they have been shown to be immunostimulatory proponents that would aid in the fight against the infection. Furthermore, additional studies are needed to elucidate the immunological mechanisms involved in these effects.

\section{Materials and Methods}

\subsection{Samples}

The samples used to perform the biological assays, hydroalcoholic extract (EHPi), ethyl acetate fraction (FAcOEt) and biflavonoids mixture (MB) were obtained by developing the work of Silva et al. [16], performed in the Laboratory of Organic Geochemistry of the Federal University of Piauí (LAGO/UFPI). The flowers of Platonia insignis Mart. were collected in the municipality of Parnarama, Maranhão state, in August 2014. The exsicata is deposited in the Graziella Barroso Herbarium, of the Federal University of Piauí (UFPI), under the ICN number TEPB 27174. The petals of fresh flowers of P. insignis were 
ground and macerated in a solvent mixture $\mathrm{EtOH} / \mathrm{H}_{2} \mathrm{O}$, in the ratio of 7:3 $(\mathrm{m} / \mathrm{v})$, in the ratio of 1:5 plant material/solvent $(\mathrm{m} / \mathrm{v})$ at room temperature, for 9 days. Subsequently, the hydroalcoholic extract (EHPi) was rotaevaporated and lyophilized. The EHPi was resuspended in $\mathrm{MeOH} / \mathrm{H}_{2} \mathrm{O}$ 9:1 $(v / v)$ and subjected to liquid-liquid partitioning with solvents in increasing order of polarity. The ethyl acetate fraction, FAcOEt, was obtained with a mass of $3.82 \mathrm{~g}$ and $\eta=26.56 \%$. From mass spectrometry with electrospray ionization in negative mode coupled to mass spectrometer (ion trap hybrid) (ESI-IT-MS) in scan mode, a mixture of biflavonoids, morelloflavone and volkensiflavone, stood out as majorities in the hydroalcoholic extract. To identify the constituents present in the FAcOEt fraction, silica dry column chromatography was performed, obtaining a subfraction, eluted with $\mathrm{MeOH} / \mathrm{H}_{2} \mathrm{O}$ 1: $1(v / v)$, presenting as a yellow amorphous solid. After ESI-MS analysis, in the negative ionization mode, and NMR, the morelloflavone compounds were identified, with the majority molecular form $\mathrm{C}_{30} \mathrm{H}_{19} \mathrm{O}_{11}$, and the volkensiflavone, whose molecular form is $\mathrm{C}_{0} \mathrm{H}_{19} \mathrm{O}_{10}$.

\subsection{Sample Preparation}

The hydroalcoholic extract (EHPi), the ethyl acetate fraction (FAcOEt) and the biflavone mixture (MB) were diluted in dimethyl sulfoxide (DMSO) to a concentration of $80 \mathrm{mg} / \mathrm{mL}$ to perform the assays. To obtain the desired concentrations $(6.25$ to $800 \mu \mathrm{g} / \mathrm{mL})$ for each protocol, the solutions were diluted in RPMI 1640 medium for macrophages or Schneider's medium for parasites, without exceeding $0.2 \%$ DMSO.

\subsection{Animals}

For the study, 4 BALB/c mice ( 20 and $30 \mathrm{~g}$, males and females, aged between 4 and 6 weeks) were used. They were kept on a $12 \mathrm{hr}$ light/dark cycle, with free access to water and food. The animals were anesthetized and euthanized with overdose of anesthetics: thiopental $(150 \mathrm{mg} / \mathrm{kg})$ and lidocaine $(10 \mathrm{mg} / \mathrm{kg})$ via intraperitoneal and subsequently euthanized by cervical dislocation, according to resolution no. 1000/2012 of the Federal Council of Veterinary Medicine, Brazil. All experiments in this study were approved by the Animal Research Ethics Committee of UFPI ( ${ }^{\circ}$. 321/17).

\subsection{Parasites and Cells}

Promastigotes of Leishmania (leishmania) amazonensis (IFLA/BR/67/PH8) were obtained from the Núcleo de Pesquisas em Plantas Medicinais da Universidade Federal do Piauí to perform the antileishmania activity assays. The parasites were grown in Schneider's medium (Sigma-Aldrich, Saint-Louis, MO, USA), supplemented with 10\% fetal bovine serum (FBS) (Sigma, USA), $100 \mathrm{U} / \mathrm{mL}$ penicillin and $100 \mu \mathrm{g} / \mathrm{mL}$ streptomycin (Sigma) and incubated at $26^{\circ} \mathrm{C}$ in a Biochemical Oxygen Demand (B. O. D.) $[38,39]$. Murine macrophages were obtained from the peritoneal cavity of BALB/c mice and cultured in RPMI 1640 medium (Sigma), supplemented with 10\% FBS, $100 \mathrm{U} / \mathrm{mL}$ penicillin and $100 \mu \mathrm{g} / \mathrm{mL}$ streptomycin at $26^{\circ} \mathrm{C}$ ).

\subsection{Antileishmanial Activity on Promastigotes}

Promastigotes of L. amazonensis in logarithmic growth phase $\left(1 \times 10^{6}\right.$ leishmania $/ 100 \mu \mathrm{L}$ medium) were seeded into 96-well cell culture plates containing supplemented Schneider's medium. Vehicle and serial dilutions of EHPi, FAcOEt, and MB samples $(800,400,200,100$, $50,25,12.5$, and $6.25 \mu \mathrm{g} / \mathrm{mL}$ ) were made on the plates and incubated in a B. O. D. at $26^{\circ} \mathrm{C}$ for $48 \mathrm{~h}$. With $6 \mathrm{~h}$ remaining, $20 \mu \mathrm{L}$ of resazurin $\left(1 \times 10^{-3} \mathrm{~mol} / \mathrm{L}\right)$ was added. Subsequently, the absorbances were read in a Biotek microplate reader (ELx800) at $550 \mathrm{~nm}$. The results were expressed in terms of growth inhibition (\%). The negative control was performed with $0.2 \%$ DMSO in Schneider's medium (vehicle) containing $1 \times 10^{6}$ promastigotes and considering $100 \%$ parasite viability. The positive control was performed with amphotericin B diluted in Schneider's medium [22]. Statistical significance was determined using one- 
way ANOVA followed by Bonferroni's post hoc test. The whole experiment was performed in triplicate of three isolated experiments.

\subsection{Determination of Cytotoxicity}

\subsubsection{Cytotoxicity on Murine Macrophages}

Cytotoxicity analyses on murine macrophages were performed in 96-well plates using the MTT (3-[4,5-dimethylthiazol-2-yl]-2,5-diphenyltetrazolium bromide) colorimetric method [40,41]. Macrophages $\left(2 \times 10^{5}\right.$ per well $)$ were incubated in $100 \mu \mathrm{L}$ of RPMI 1640 medium at $37^{\circ} \mathrm{C}$ in $5 \% \mathrm{CO}_{2}$ for $4 \mathrm{~h}$ for cell adhesion to the coverslips. The wells were washed with RPMI 1640 medium to remove cells that did not adhere. Vehicle, $\mathrm{EHPi}, \mathrm{FAcOEt}$ and $\mathrm{MB}$ were diluted at different concentrations $(6.25,12.5,25,50,100$, 200, 400 and $800 \mu \mathrm{g} / \mathrm{mL}$ ) were added to the wells and incubated at $37{ }^{\circ} \mathrm{C}$ at $5 \% \mathrm{CO}_{2}$ for $48 \mathrm{~h}$. Subsequently, $10 \mu \mathrm{L}$ of MTT $(5 \mathrm{mg} / \mathrm{mL})$ diluted in $100 \mu \mathrm{L}$ of RPMI medium was added and incubated at $37^{\circ} \mathrm{C}$ in $5 \% \mathrm{CO}_{2}$ for $4 \mathrm{~h}$. After the incubation period, the supernatant was discarded, $100 \mu \mathrm{L}$ of DMSO was added, the plates were shaken on a Kleine plate shaker for $30 \mathrm{~min}$, and readings were taken on a Biotek plate reader (Elx800) at $550 \mathrm{~nm}$. The absorbance obtained from the untreated cells was considered as $100 \%$ cell viability. Statistical significance was determined using One-way ANOVA followed by Bonferroni's post hoc test. The whole experiment was performed in triplicate of three isolated experiments.

\subsubsection{Hemolytic Activity}

For evaluation of hemolytic activity, as described by Alves et al. [22], sheep erythrocytes were diluted in $80 \mu \mathrm{L}$ of phosphate-buffered saline (PBS) to adjust concentration to $5 \%$ hematocrit and incubated at $37^{\circ} \mathrm{C}$ with serial concentrations of vehicle, EHPi, FAcOEt, and MB $(6.25$ to $800 \mu \mathrm{g} / \mu \mathrm{L})$ diluted in $20 \mu \mathrm{L}$ of PBS. After $1 \mathrm{hr}, 200 \mu \mathrm{L}$ of PBS was added to stop the reaction and the suspensions were centrifuged at $1000 \times \mathrm{g}$ for $10 \mathrm{~min}$. The supernatants were transferred to 96 -well plates. Cell lysis was determined by reading the absorbance at $550 \mathrm{~nm}$. The presence of 100\% hemolysis (positive control) and the absence of hemolysis (negative control) were determined by replacing the tested samples with equal volume of sterile Milli-Q water and PBS, respectively. The percentage of hemolysis obtained was determined by comparison with the positive control, $100 \%$ hemolysis [42]. Statistical significance was determined using One-way ANOVA followed by Bonferroni's post hoc test. The entire experiment was performed in triplicate of three isolated experiments.

\subsubsection{Activity of EHPI, FAcOEt and MB on L. amazonensis-Infected Macrophages}

Macrophages $\left(2 \times 10^{5}\right.$ cells $\left./ \mathrm{mL}\right)$ were plated in 24-well plates in supplemented RPMI medium (10\% FBS, penicillin $100 \mathrm{U} / \mathrm{mL}$, and streptomycin $100 \mu \mathrm{g} / \mathrm{mL})$ and incubated at $37{ }^{\circ} \mathrm{C}$ in $5 \% \mathrm{CO}_{2}$ for $3 \mathrm{~h}$ for cell adhesion. The macrophages were again incubated with medium containing the promastigote forms $\left(2 \times 10^{6}\right)$, in stationary growth phase, at the ratio of 10 promastigotes to 1 macrophage, in $5 \% \mathrm{CO}_{2}$ at $37{ }^{\circ} \mathrm{C}$ for $4 \mathrm{~h}$. After this time, the supernatants were aspirated to remove the non-internalized parasites. After infection, the wells were washed with $0.1 \mathrm{M}$ PBS. The infected macrophages were incubated with vehicle, EHPi at 7.5, 15 and $30 \mu \mathrm{g} / \mathrm{mL}$ (concentrations non-toxic to cells), FAcOEt and $\mathrm{MB}$ at 15, 30 and $60 \mu \mathrm{g} / \mathrm{mL}$ (concentrations non-toxic to cells) and Amphotericin $\mathrm{B}$ at $0.2 \mu \mathrm{g} / \mathrm{mL}$ for $48 \mathrm{hrs}$. Subsequently, the coverslips were removed and fixed with Panotic (Laborclin, Paraná, Brazil). The number of infected macrophages and the number of amastigotes per macrophage were determined by reading the number of parasites in 100 macrophages. Then, selectivity indices were determined by the average ratio of $50 \%$ cytotoxic concentration (CC50) for macrophages by $50 \%$ effective concentration (EC50) for amastigotes internalized in macrophages [43]. Statistical significance was determined using one-way ANOVA followed by Bonferroni's post hoc test. The entire experiment was performed in triplicate of three isolated experiments. 
4.7. Immunomodulatory Mechanisms of Macrophage Activation Induced by EHPi, FAcOEt and MB Samples

\subsubsection{Lysosomal Activity}

Murine macrophages $\left(2 \times 10^{5}\right.$ cells/well) were incubated with vehicle, EHPi, FAcOEt and $\mathrm{MB}(5.625$ to $90 \mu \mathrm{g} / \mathrm{mL})$ and with Amphotericin B $(0.2 \mu \mathrm{g} / \mathrm{mL})$ in 96 -well plates at $37^{\circ} \mathrm{C}$ and $5 \% \mathrm{CO}_{2}$. After $48 \mathrm{~h}, 10 \mu \mathrm{L}$ of the $2 \%$ neutral red solution in DMSO was added and incubated for another $30 \mathrm{~min}$. Subsequently, the supernatants were discarded, the wells were washed with $0.9 \%$ saline at $37{ }^{\circ} \mathrm{C}$ and the neutral red retained in the lysosomal vesicles were solubilized by adding $100 \mu \mathrm{L}$ of extraction solution ( $1 \%$ glacial acetic acid $(v / v)$ and $50 \%$ ethanol $(v / v)$ dissolved in distilled water). After 30 min of shaking the plates, the absorbances were read on a Biotek plate reader (Elx800) at $550 \mathrm{~nm}$ [44]. Statistical significance was determined using one-way ANOVA followed by Bonferroni's post hoc test.

\subsubsection{Evaluation of Phagocytic Capacity}

Murine macrophages $\left(2 \times 10^{5}\right.$ cells/well) were incubated with vehicle, EHPi, FAcOEt and $\mathrm{MB}(5.625$ to $90 \mu \mathrm{g} / \mathrm{mL})$ and with Amphotericin B $(0.2 \mu \mathrm{g} / \mathrm{mL})$ in 96 -well plates at $37^{\circ} \mathrm{C}$ and $5 \% \mathrm{CO}_{2}$. After $48 \mathrm{~h}, 10 \mu \mathrm{L}$ of zymosan solution stained with neutral red was added and incubated for $30 \mathrm{~min}$. Subsequently, the plates were washed with $0.9 \%$ saline and $100 \mu \mathrm{L}$ of extraction solution was added. After solubilization in a plate shaker, absorbances were read in a Biotek plate reader (Elx800) at $550 \mathrm{~nm}$ [45]. Statistical significance was determined using one-way ANOVA followed by Bonferroni's post hoc test.

\subsubsection{Evaluation of Nitric Oxide Production}

To evaluate nitrite production by peritoneal macrophages from BALB/c mice, macrophages were plated $\left(2 \times 10^{5}\right.$ cells/well) in 96-well plates and incubated for $4 \mathrm{~h}$ at $37{ }^{\circ} \mathrm{C}$ in $5 \% \mathrm{CO}_{2}$ for cell adhesion. After this time, the supernatants were removed to eliminate macrophages that did not adhere and incubated after the addition of vehicle, EHPi, FAcOEt, and MB at concentrations of 5.625 to $90 \mu \mathrm{g} / \mathrm{mL}$. After incubation for $24 \mathrm{~h}$ at $37{ }^{\circ} \mathrm{C}$ in $5 \% \mathrm{CO}_{2}$, the supernatants were transferred to other 96 -well plates for nitrite dosage. Standard curves were prepared with sodium nitrite in RPMI medium in concentration range ranging from 1.1 to $600 \mu \mathrm{M}$ diluted in RPMI medium. The samples (supernatants) or the solutions prepared to obtain the standard curve with the same volume of Griess reagent (1\% Sulfanilamide in $\mathrm{H}_{3} \mathrm{PO}_{4} 10 \% v / v$ in Milli-Q®water) were mixed in a $1: 1$ ratio with $0.1 \%$ naphthylenediamine in Milli-Q water and absorbance readings were taken in a Biotek plate reader (ELx800) at $550 \mathrm{~nm}$. DMSO (0.5\%) in RPMI medium was used as control [46]. Statistical significance was determined using one-way ANOVA followed by Bonferroni's post hoc test.

Author Contributions: Conceptualization: É.A.B. and D.D.R.A.; methodology: M.M.d.M.A., F.A.d.A.C. and D.D.R.A.; formal analysis and investigation: E.E.A.P. and L.V.A.; writing-original draft preparation: É.A.B., S.K.R.L. and M.M.d.M.A.; writing—review and editing: D.D.R.A., M.M.d.M.A. and J.d.S.L.N.; resources: S.K.R.L., F.A.d.A.C., A.M.d.G.L.C. and D.D.R.A.; supervision: M.M.d.M.A., A.M.d.G.L.C. and F.A.d.A.C. All authors have read and agreed to the published version of the manuscript.

Funding: Fundação de Amparo à Pesquisa do Estado do Maranhão-FAPEMA (Edital Nº 05/2021— Apoio a Publicação de Artigos); Fundação de Amparo à Pesquisa do Estado do Piauí-FAPEPI (Edital FAPEPI Nº 008/2016-Popularização da Ciência).

Institutional Review Board Statement: O estudo conduzido foi aprovado pela Comissão de Ética no Uso de Animais da Universidade Federal do Piauí (no. 321/17).

Informed Consent Statement: Not applicable.

Data Availability Statement: Original data from experiments will be available under request.

Acknowledgments: We are grateful to the Fundação de Amparo à Pesquisa do Estado do Maranhão (FAPEMA), and the Coordination for the Improvement of Higher Education Personnel (CAPES). 
Conflicts of Interest: The authors declare no conflict of interest. Similarly, funders had no role in the design of the study or in the collection, analysis or interpretation of data.

\section{References}

1. World Health Organization. Control of Neglected Tropical Diseases. Available online: https://www.who.int/news/item/27-052021-world-health-assembly-adopts-decision-to-recognize-30-january-as-world-ntd-day (accessed on 13 August 2021).

2. World Health Organization. Global leishmaniasis Surveillance, 2017-2018, and First Report on 5 Additional Indicators. Control Negl. Trop. Dis. 2020, 95, 265-280.

3. World Health Organization. Leishmaniasis. Available online: https://www.who.int/news-room/fact-sheets/detail/ leishmaniasis (accessed on 30 May 2021).

4. $\quad$ Roatt, B.M.; de Oliveira Aguiar-Soares, R.D.; Coura-Vital, W.; Ker, H.G.; das Dores Moreira, N.; Vitoriano-Souza, J.; Giunchetti, R.C.; Carneiro, C.M.; Reis, A.B. Immunotherapy and immunochemotherapy in visceral leishmaniasis: Promising treatments for this neglected disease. Front. Immunol. 2014, 5, 1-12. [CrossRef] [PubMed]

5. Pinheiro, I.M.; Carvalho, I.P.S.; Neto, J.A.T.; Lopes, G.L.N.; de Sousa Coêlho, E.; Sobrinho-Júnior, E.P.C.; de Moraes Alves, M.M.; de Amorim Carvalho, F.A.; Carvalho, A.L.M. Amphotericin B-loaded emulgel: Effect of chemical enhancers on the release profile and antileishmanial activity in vitro. AAPS PharmSciTech 2019, 20, 122. [CrossRef]

6. Oliveira, L.F.; Gilbert, B.; Villas-Bôas, G. Oportunidades para inovação no tratamento da leishmaniose usando o potencial das plantas e produtos naturais como fontes de novos fármacos. Rev. FITOS 2013, 8, 33-42. [CrossRef]

7. Filho, V.C.; Yunes, R.A. Strategies for obtaining pharmacologically active compounds from medicinal plants. Concepts about structural modification for improve the activity. Quim. Nova 1998, 21, 99-105. [CrossRef]

8. Lovkova, M.Y.; Buzuk, G.N.; Sokolova, S.M.; Kliment'eva, N.I. Chemical features of medicinal plants (review). Appl. Biochem. Microbiol. 2001, 37, 229-237. [CrossRef]

9. $\quad$ Costa Júnior, J.S.; Ferraz, A.B.F.; Sousa, T.O.; Silva, R.A.C.; De Lima, S.G.; Feitosa, C.M.; Citó, A.M.G.L.; Melo Cavalcante, A.A.C.; Freitas, R.M.; Moura Sperotto, A.R.; et al. Investigation of biological activities of dichloromethane and ethyl acetate fractions of Platonia insignis Mart. seed. Basic Clin. Pharmacol. Toxicol. 2013, 112, 34-41. [CrossRef] [PubMed]

10. Costa Júnior, J.S.; Ferraz, A.B.F.; Filho, B.A.B.; Feitosa, C.M.; Citó, A.M.G.L.; Freitas, R.M.; Saffi, J. Evaluation of antioxidant effects in vitro of garcinielliptone FC (GFC) isolated from Platonia insignis mart. J. Med. Plants Res. 2011, 5, $293-299$.

11. Da Costa, J.S.; De Almeida, A.A.C.; da Rocha Tomé, A.; das Graças Lopes Citó, A.M.; Saffi, J.; De Freitas, R.M. Evaluation of possible antioxidant and anticonvulsant effects of the ethyl acetate fraction from Platonia insignis Mart. (Bacuri) on epilepsy models. Epilepsy Behav. 2011, 22, 678-684. [CrossRef] [PubMed]

12. Costa Júnior, J.S.; de Almeida, A.A.C.; Ferraz, A.D.B.F.; Rossatto, R.R.; Silva, T.G.; Silva, P.B.N.; Militão, G.C.G.; Citó, A.M.D.G.L.; Santana, L.C.L.R.; Carvalho, F.A.D.A.; et al. Cytotoxic and leishmanicidal properties of garcinielliptone FC, a prenylated benzophenone from Platonia insignis. Nat. Prod. Res. 2013, 27, 470-474. [CrossRef]

13. Lustosa, A.K.M.F.; Arcanjo, D.D.R.; Ribeiro, R.G.; Rodrigues, K.A.F.; Passos, F.F.B.; Piauilino, C.A.; Silva-Filho, J.C.; Araújo, B.Q.; Lima-Neto, J.S.; Costa-Júnior, J.S.; et al. Immunomodulatory and toxicological evaluation of the fruit seeds from Platonia insignis, a native species from Brazilian Amazon rainforest. Rev. Bras. Farmacogn. 2016, 26, 77-82. [CrossRef]

14. Rufino, S.M.; Alves, R.E.; De Brito, E.S.; Pérez-jiménez, J.; Saura-calixto, F.; Mancini-filho, J. Bioactive compounds and antioxidant capacities of 18 non-traditional tropical fruits from Brazil. Food Chem. 2010, 121, 996-1002. [CrossRef]

15. Food and Agriculture Organization of the United Nations (FAO). Fruit Trees and Useful Plants in Amazonian Life: Non-Wood Forest Products, 20; Center for International Forestry Research (CIFOR) and People and Plants International (PPI): Rome, Italy, 2011; Volume 53, ISBN 9788578110796. Available online: http:/ /www.fao.org/3/i2360e/i2360e.pdf (accessed on 30 August 2021).

16. e Silva, A.K.F.; dos Reis, A.C.; Pinheiro, E.E.A.; de Sousa, J.N.; de Alcântara Oliveira, F.A.; Moura, A.K.S.; de Sousa, L.; Neto, J.; das Graças, L.; Citó, A.M.; et al. Modulation of the drug resistance by platonia insignis mart. extract, ethyl acetate fraction and morelloflavone/volkensiflavone (Biflavonoids) in staphylococcus aureus strains overexpressing efflux pump genes. Curr. Drug Metab. 2021, 22, 114-122. [CrossRef] [PubMed]

17. Lin, Y.M.; Anderson, H.; Flavin, M.T.; Pai, Y.H.S.; Mata-Greenwood, E.; Pengsuparp, T.; Pezzuto, J.M.; Schinazi, R.F.; Hughes, S.H.; Chen, F.C. In Vitro anti-HIV activity of biflavonoids isolated from Rhus succedanea and Garcinia multiflora. J. Nat. Prod. 1997, 60, 884-888. [CrossRef]

18. Gontijo, V.S.; De Souza, T.C.; Rosa, I.A.; Soares, M.G.; Da Silva, M.A.; Vilegas, W.; Viegas, C.; Dos Santos, M.H. Isolation and evaluation of the antioxidant activity of phenolic constituents of the Garcinia brasiliensis epicarp. Food Chem. 2012, 132, 1230-1235. [CrossRef]

19. Otuki, M.F.; Bernardi, C.A.; Prudente, A.S.; Laskoski, K.; Gomig, F.; Horinouchi, C.D.S.; Guimarães, C.L.; Ferreira, J.; DelleMonache, F.; Cechinel-Filho, V.; et al. Garcinia gardneriana (Planchon \& Triana) Zappi. (Clusiaceae) as a topical anti-inflammatory alternative for cutaneous inflammation. Basic Clin. Pharmacol. Toxicol. 2011, 109, 56-62. [CrossRef]

20. Verdi, L.G.; Pizzolatti, M.G.; Montanher, A.B.P.; Brighente, I.M.C.; Smânia Júnior, A.; Smânia, E.D.F.A.; Simionatto, E.L.; Monache, F.D. Antibacterial and brine shrimp lethality tests of biflavonoids and derivatives of Rheedia gardneriana. Fitoterapia 2004, 75, 360-363. [CrossRef]

21. Tuansulong, K.A.; Hutadilok-Towatana, N.; Mahabusarakam, W.; Pinkaew, D.; Fujise, K. Morelloflavone from Garcinia dulcis as a novel biflavonoid inhibitor of HMG-CoA reductase. Phyther. Res. 2011, 25, 424-428. [CrossRef] 
22. Alves, M.M.M.; Brito, L.M.; Souza, A.C.; Queiroz, B.C.S.H.; de Carvalho, T.P.; Batista, J.F.; Oliveira, J.S.S.M.; de Mendonça, I.L.; Lira, S.R.S.; Chaves, M.H.; et al. Gallic and ellagic acids: Two natural immunomodulator compounds solve infection of macrophages by Leishmania major. Naunyn. Schmiedebergs. Arch. Pharmacol. 2017, 390, 893-903. [CrossRef]

23. Carvalho, C.E.S.; Sobrinho-Junior, E.P.C.; Brito, L.M.; Nicolau, L.A.D.; Carvalho, T.P.; Moura, A.K.S.; Rodrigues, K.A.F.; Carneiro, S.M.P.; Arcanjo, D.D.R.; Citó, A.M.G.L.; et al. Anti-Leishmania activity of essential oil of Myracrodruon urundeuva (Engl.) Fr. All.: Composition, cytotoxity and possible mechanisms of action. Exp. Parasitol. 2017, 175, 59-67. [CrossRef]

24. Silva, T.; Oliveira, A. Leishmanicidal plants from Brazilian Amazonia: A review. Rev. Fitos 2016, 10, 339-363. [CrossRef]

25. Frescura, V.D.S.; Kuhn, A.W.; Laughinghouse IV, H.D.; Paranhos, J.T.; Tedesco, S.B. Post-treatment with plant extracts used in Brazilian folk medicine caused a partial reversal of the antiproliferative effect of glyphosate in the Allium cepa test. Biocell 2013, 37, 23-28. [CrossRef] [PubMed]

26. Silva, R.; Vale, L.; Calou, B.F.; De Deus, M.; Socorro, M.; Pinheiro, P.M.; Paula, A. Flavonoids: Chemical composition, medical actions and toxicity. Acta Toxicológica Argent. 2015, 23, 36-43.

27. Silva, F.; Sales, M.; Sá, O.; Santana, G.; Deus, M.; Sousa, J.; Ferreira, P.; Peron, A. Potencial citotóxico, genotóxico e citoprotetor de extratos aquosos de Caesalpinia Pyramidalis tul., Caesalpinia Ferrea Mart. e Caesalpinia Pulcherrima Sw. Rev. Bras. Biociências 2015, 101-109.

28. Wagner, H. Search for potent immunomodulatory agents from plants and other sources. In Bioassay Methods in Natural Product Research and Drug Development; Springer: Dordrecht, The Netherlands, 1999; pp. 113-118. [CrossRef]

29. Islamuddin, M.; Chouhan, G.; Farooque, A.; Dwarakanath, B.S.; Sahal, D.; Afrin, F. Th1-Biased immunomodulation and therapeutic potential of artemisia annua in murine visceral leishmaniasis. PLoS Negl. Trop. Dis. 2015, 9, e3321. [CrossRef] [PubMed]

30. Trinchieri, G. Cytokines acting on or secreted by macrophages during intracellular infection (IL-10, IL-12, IFN- $\gamma$ ). Curr. Opin. Immunol. 1997, 9, 17-23. [CrossRef]

31. Gordon, S. Alternative activation of macrophages. Nat. Rev. Immunol. 2003, 3, 23-35. [CrossRef]

32. Wei, W.C.; Su, Y.H.; Chen, S.S.; Sheu, J.H.; Yang, N.S. GM-CSF plays a key role in zymosan-stimulated human dendritic cells for activation of Th1 and Th17 cells. Cytokine 2011, 55, 79-89. [CrossRef]

33. Krishnatry, A.S.; Brazeau, D.A.; Fung, H.L. Broad regulation of matrix and adhesion molecules in THP-1 human macrophages by nitroglycerin. Nitric Oxide-Biol. Chem. 2010, 22, 11-17. [CrossRef] [PubMed]

34. MacMicking, J.; Xie, Q.W.; Nathan, C. Nitric oxide and macrophage function. Annu. Rev. Immunol. 1997, 15, 323-350. [CrossRef]

35. Melo Neto, B.; Leitão, J.M.S.R.; Oliveira, L.G.C.; Santos, S.E.M.; Carneiro, S.M.P.; Rodrigues, K.A.F.; Chaves, M.H.; Arcanjo, D.D.R.; Carvalho, F.A.A. Inhibitory effects of Zanthoxylum rhoifolium lam. (Rutaceae) against the infection and infectivity of macrophages by Leishmania amazonensis. An. Acad. Bras. Ciências 2016, 88, 1851-1861. [CrossRef]

36. Kayser, O.; Kiderlen, A.F.; Croft, S.L. Natural products as antiparasitic drugs. Parasitol. Res. 2003, 90, 55-62. [CrossRef] [PubMed]

37. Sen, R.; Chatterjee, M. Plant derived therapeutics for the treatment of Leishmaniasis. Phytomedicine 2011, 18, 1056-1069. [CrossRef] [PubMed]

38. Carneiro, S.M.P.; Carvalho, F.A.A.; Santana, L.C.L.R.; Sousa, A.P.L.; Neto, J.M.M.; Chaves, M.H. The cytotoxic and antileishmanial activity of extracts and fractions of leaves and fruits of Azadirachta indica (A Juss.). Biol. Res. 2012, 45, 111-116. [CrossRef]

39. Valadares, D.G.; Duarte, M.C.; Oliveira, J.S.; Chávez-Fumagalli, M.A.; Martins, V.T.; Costa, L.E.; Leite, J.P.V.; Santoro, M.M.; Régis, W.C.B.; Tavares, C.A.P.; et al. Leishmanicidal activity of the Agaricus blazei Murill in different Leishmania species. Parasitol. Int. 2011, 60, 357-363. [CrossRef]

40. De Medeiros, M.D.G.F.; da Silva, A.C.; Citó, A.M.D.G.L.; Borges, A.R.; de Lima, S.G.; Lopes, J.A.D.; Figueiredo, R.C.B.Q. In vitro antileishmanial activity and cytotoxicity of essential oil from Lippia sidoides Cham. Parasitol. Int. 2011, 60, 237-241. [CrossRef]

41. Gonçalves, J.C.R.; Coulidiati, T.H.; Monteiro, A.L.; de Carvalho-Gonçalves, L.C.T.; de Oliveira Valença, W.; de Oliveira, R.N.; de Amorim Câmara, C.; de Araújo, D.A.M. Antitumoral activity of novel 1,4-naphthoquinone derivative involves L-type calcium channel activation in human colorectal cancer cell line. J. Appl. Biomed. 2016, 14, 229-234. [CrossRef]

42. Löfgren, S.E.; Miletti, L.C.; Steindel, M.; Bachère, E.; Barracco, M.A. Trypanocidal and leishmanicidal activities of different antimicrobial peptides (AMPs) isolated from aquatic animals. Exp. Parasitol. 2008, 118, 197-202. [CrossRef] [PubMed]

43. De Castro Oliveira, L.G.; Brito, L.M.; de Moraes Alves, M.M.; Amorim, L.V.; Sobrinho-Júnior, E.P.C.; de Carvalho, C.E.S.; da Franca Rodrigues, K.A.; Arcanjo, D.D.R.; das Graças Lopes Citó, A.M.; de Amorim Carvalho, F.A. In Vitro Effects of the Neolignan 2,3-Dihydrobenzofuran Against Leishmania Amazonensis. Basic Clin. Pharmacol. Toxicol. 2017, 120, 52-58. [CrossRef] [PubMed]

44. Bonatto, S.J.R.; Folador, A.; Aikawa, J.; Yamazaki, R.K.; Pizatto, N.; Oliveira, H.H.P.; Vecchi, R.; Curi, R.; Calder, P.C.; Fernandes, L.C. Lifelong exposure to dietary fish oil alters macrophage responses in Walker 256 tumor-bearing rats. Cell. Immunol. 2004, 231, 56-62. [CrossRef] [PubMed]

45. Grando, F.C.C.; Felício, C.A.; Twardowschy, A.; Paula, F.M.; Batista, V.G.; Fernandes, L.C.; Curi, R.; Nishiyama, A. Modulation of peritoneal macrophage activity by the saturation state of the fatty acid moiety of phosphatidylcholine. Braz. J. Med. Biol. Res. 2009, 42, 599-605. [CrossRef] [PubMed]

46. Soares, D.C.; Pereira, C.G.; Meireles, M.Â.A.; Saraiva, E.M. Leishmanicidal activity of a supercritical fluid fraction obtained from Tabernaemontana catharinensis. Parasitol. Int. 2007, 56, 135-139. [CrossRef] [PubMed] 